УДК 331.108 .4

\title{
УНІВЕРСАЛЬНА МОДЕЛЬ КОМПЕТЕНТНОСТЕЙ ДЛЯ РОБОТИ У ДИСТАНЦІЙНОМУ РЕЖИМІ
}

\section{UNIVERSAL COMPETENCY MODEL FOR WORKING IN REMOTE MODE}

\author{
Волобоєва Ірина Олександрівна \\ кандидат економічних наук, доцент, \\ Київський національний економічний університет імені Вадима Гетьмана \\ ORCID: https://orcid.org/0000-0002-9502-5045 \\ Кравчук Оксана Іванівна \\ кандидат економічних наук, доцент, \\ Київський національний економічний університет імені Вадима Гетьмана \\ ORCID: https://orcid.org/0000-0002-6337-7759 \\ Паращук Єлизавета Юріївна \\ здобувач вищої освіти, \\ Київський національний економічний університет імені Вадима Гетьмана \\ ORCID: https://orcid.org/0000-0002-1614-3589
}

\author{
Voloboieva Iryna, Kravchuk Oksana, Parashchuk Yelyzaveta \\ Kyiv National Economic University named after Vadym Hetman
}

\begin{abstract}
У статті представлено методологічний аспект формування та впровадження універсальної моделі компетентностей для працівників, що перейшли на дистанційний режим роботи, що й визначає актуальність та новизну дослідження. Наведено теоретичний аналіз понять "компетенція" і "компетентність". Установлений взаємозв'язок між ними і обґрунтоване їх розмежування. Авторами досліджено соціальні та особистісні аспекти компетентності працівника, який перейшов на дистанційний фрормат роботи. Розроблено профіль соціально-особистісних компетентностей. Проведено професійне опитування та обґрунтовано важливість наявності компетентностей у працівників, що працюють у дистанційному режимі. Виокремлено поведінкові індикатори для ключових компетентностей. Запропонована універсальна модель компетентностей. Розраховані відповідні вагові коефріцієнти компетентностей на основі експертного опитування. Розроблено рекомендації для втілення представленої моделі та оцінювання працівників, прийняття відповідних управлінських рішень.

Ключові слова: компетентність, компетенція, дистанційний режим, модель компетентностей, оцінювання працівників.
\end{abstract}

В статье представлен методологический аспект формирования и внедрения универсальной модели компетентностей для работников, которые перешли на дистанционный режим работы, что и определяет актуальность и новизну исследования. Приведен теоретический анализ понятий "компетенция" и "компетентность". Установлена взаимосвязь между ними и обосновано их разграничение. Авторами исследованы социальные и личностные аспекты компетентности сотрудника, перешедшего на дистанционный фрормат работы. Разработан профиль социально-личностных компетентностей. Проведен профессиональный опрос и обоснована важность наличия компетентностей у персонала, переведенного на дистанционный режим. Выделены поведенческие индикаторы для ключевых компетентностей. Предложена универсальная модель компетентностей. Рассчитаны соответствующие весовые коэфрфициенты компетентностей на основе экспертного опроса. Разработаны рекомендации для воплощения представленной модели и оценки работников, принятия соответствующих управленческих решений.

Ключевые слова: компетентность, компетенция, дистанционный режим, модель компетентностей, оценивание сотрудников.

The relevance of scientific research is determined by an event that is becoming increasingly important and widespread, namely, the COVID-19 pandemic, which has quickly changed companies' approaches to work and carried out serious checks in various processes and systems. The staff nowadays carries knowledge, skills and abilities, 
and the employee becomes the leading factor in the development of any organization and the main factor in the formation of its stable competitive advantages. In this article, we have studied the methodological aspect of the formation and implementation of a universal model of competencies for employees who have switched to remote work, which determines the relevance and novelty in authors' views. The authors give a theoretical analysis to understand "competence" and "competency", based on research in the scientific literature, the main approaches to the interpretation of data to understand are considered and presented. The relationship between them is established and their differentiation is justified as well. We have investigated the social and personal aspects of the competence of an employee who switched to working remotely. A profile of social and personal competencies has also been developed. The authors conducted a survey, the target audience of which was chosen as the social networks Linkedln and Facebook, namely HR directors, managers, business partners and employers. The research we have justified the importance of having the selected competencies among employees working remotely; identified the necessary level of proficiency in each of them; described behavioral indicators for key competencies. Based on the obtained results, the authors propose a universal model of competences. Taking into consideration the Likert total rating scale and the results of the conducted expert survey among experts from among experienced HR specialists and HR directors of various companies in Ukraine, we have calculated weighting coefficients. We have worked out recommendations for evaluating employees using the Harington scale and estimated coefficients, implementing an effective remote working mode, making appropriate management decisions, among which we suggest the next: organizing training for the employee, organizing a blended-online and in person mode and providing a greater share of responsibility to the employee and the ability to make independent decisions.

Keywords: competence, competency, working remotely, competence model, employee assessment.

Постановка проблеми. Питання підвищення продуктивності та результативності праці працівників залишається пріоритетним завданням керівництва сучасних компаній. Одним зі шляхів вирішення цього завдання $€$ вдосконалення профресійних якостей співробітників, для оцінки яких необхідні критерії просресійної компетентності. Складні умови, в яких знаходяться компанії даний час, диктують нові вимоги до співробітників. Це пов'язано, перш за все, з тим, що пандемія COVID-19 швидко змінила підходи компаній до роботи та здійснила серйозні перевірки в різних процесах та системах. Бізнес щодня стикається з новими викликами та пріоритетними напрямами ризиками зупинення та бізнесу, швидким прийняттям рішень в віртуальному та реальному часі, показниками продуктивності та результативності праці, загрозами безпеці. В таких випадках керівники повинні діяти дуже гнучко та оперативно, вирішуючи проблеми пріоритетних напрямів, процесів та стійкості систем. Тим самим створюючи шлях в майбутнє своїх компаній. У зв'язку з цим доцільно говорити про працівника підприємства нового покоління. Ідеальний працівник в сучасних умовах - це зразок професіонала, носій цивільних, виробничих та особистісних фрункцій, сорормованих на найвищому рівні. Тому одним 3 важливих професійних якостей працівника $є$ просресійна компетентність. При цьому працівник реалізує себе як спеціаліст, виконуючи свої обов'язки в системі трудових відносин.

На сучасних підприємствах рекрутери, проводячи співбесіди, дуже часто проводять інтерв'ю за компетентностями. У профрілі посади та в заявці на підбір керівник має вказати основні компетентності, якими повинен володіти "ідеальний" кандидат. Для сьогодення $€$ характерним сприйняття даної категорії, як певний набір якостей, який змінюється залежно від посади та оцінюється HR-менеджерами при прийнятті спеціаліста на роботу. Тому розуміння значення кожної компетентності, вміння розмежовувати їх з іншими та виділяти найголовніші, наймаючи працівників відповідно на різні посади $є$ важливим.

Аналіз останніх досліджень та публікацій. Вагомий внесок у дослідження категорії "компетенція" зробили такі вчені-економісти: М. Армстронг, Г. Беккер, Л.М. Спенсер і С.М. Спенсер та ін. Ґрунтовний теоретичний аналіз понять "компетенція" і "компетентність" працівників організацій здійснили зарубіжні вчені такі, як Ч. Вудруфр, Д. Гелбрейт, Л. Едвінссон, Дж. Іванцевич, Дж. Кендрик, Дж. Лафти, Ф. Махлуп, М. Мелоун, К. Свейбі, Д. Торрінгтон та ін. Питанню класифікації компетенцій та фрормуванню моделей приділяє увагу чимало українських авторів. У публікаціях А.М. Колота [1], Г.С. Лопушняк [2], І.Л. Петрової [3], С.О. Цимбалюк [4] та попередніх працях авторів даної статті [5; 6] приділено уваги визначенню нових вимог до людських ресурсів та тенденціям їх трансорормації відповідно до сучасних потреб бізнесу в новій соціально-економічній реальності. Але досі існують суттєві моменти стосовно цієї теми, які потребують вирішення, враховуючи сучасні події, які відбуваються у світі. Тому актуальним залишається змістовний аналіз різних наукових підходів до тлумачення цих питань та пояснення їх сутності. Наразі немає єдиного бачення переліку компетент- 
ностей працівника, потреба в яких виникає в зв'язку з новими способами організації трудової діяльності в дистанційному режимі, особливо під час пандемії COVID-19. Тому очевидною $є$ незбіжність вироблення підходів до фрормування універсальної моделі компетентностей працівника, яка була б оптимальною для застосування різними компаніями світу в сучасних умовах.

Виділення невирішених раніше частин загальної проблеми. Пандемія коронавірусу в усьому світі змусила роботодавців перевести багатьох своїх працівників на дистанційний режим роботи. Такий формат став новим та незвичним для більшості працюючих: бракує досвіду, виникають труднощі в концентрації уваги для виконання завдань, та інші фрактори, які відволікають від роботи. Керівникам, які раніше керували роботою працівників в межах офрісу, бракує досвіду організовувати виконання поставлених завдань 3 дому. Важливим виявляються питання - "Як працювати в дистанційному режимі та зберегти продуктивність праці, не втратити командний дух та отримати якісні результати?" та “Як оцінити роботу працівників, які виконують свої професіональні обов'язки в дистанційному режимі?". Тому наразі стало дуже актуальним фрормування загальної моделі компетентностей для фрахівців, переведених на дистанційний режим роботи.

Формулювання цілей статті. Метою статті $€$ проведення теоретичного аналізу різних поглядів щодо трактувань понять "компетенція", "компетентність", розкриття їх сутності та розроблення рекомендацій щодо фрормування універсальної моделі компетентностей для працівників, які перейшли на дистанційний режим роботи.

Виклад основного матеріалу дослідження. Світова практика показує, що компетентність $€$ ключовим в змісті навчання та роботи, тому що інтеграційна природа, яка закладена в сутності цього поняття, поєднує знання, навички, вміння та інтелектуальний потенціал людини. Тлумачні та енциклопедичні словники дають змогу глибше зрозуміти неоднозначність та багатотрактовність зазначених понять. Англійське слово "competence" у свій час у науковому світі викликало багато питань та дискусій щодо значень понять "компетентність" і “компетенція", їх змісту та ієрархії. У вітчизняному науковому просторі ці поняття $€$ ключовими у вищій освіті. Це означає, що вони повинні мати лише одне значення, але у документах МОН від 2007 року та Законі України "Про освіту" від 2017 року ці поняття перекладаються та визначаються по-різному [7]. Закон України "Про вищу освіту" чітко розмежовує ці поняття. Так, визначення вищої освіти як "сукупності систематизованих знань, умінь і практичних навичок, способів мислення, профресійних, світоглядних і громадянських якостей, морально-етичних цінностей, інших компетентностей, здобутих у вищому навчальному закладі (науковій установі)..." та результатів навчання (як "сукупності знань, умінь, навичок, інших компетентностей, набутих особою у процесі навчання за певною освітньо-профресійною, освітньо-науковою програмою, які можна ідентифрікувати, кількісно оцінити та виміряти" [7] фрормують розуміння компетентності фрахівця 3 вищою освітою як певної множини компетентностей, які він здобуває під час навчання у вищому навчальному закладі. Зазначимо, що у документах Болонського процесу та у проекті TUNING англійське слово «competence» вживається для позначення результатів навчання, перекладається дослідниками на українську як два терміни "компетентність" і "компетенція". У 2007 році Міністерство освіти і науки у Комплексі нормативних документів слово «competences» переклало як "компетенції". Закон України "Про вищу освіту" використовує термін "компетентності" для визначення результатів навчання. Таким чином, виникли розбіжності між трактуванням при перекладі терміну "competence" та значенням і змістом в українській мові та науковому вітчизняному просторі. [8]. Так як у наукові літературі виникла невелика плутанина з поняттями "компетентність" та "компетенція", з їх значеннями та використанням, пропонуємо посилатися на Закон України про освіту, який визначає, що компетентність - динамічна комбінація знань, умінь, навичок, способів мислення, поглядів, цінностей, інших особистих якостей, що визначає здатність особи успішно соціалізуватися, проводити професійну та/або подальшу навчальну діяльність [7].

Продовжуючи вивчати поняття компетентність та моделі компетентностей різних профресій, класифрікації, слід зазначити, що немає чіткого єдиного підходу до переліку компетентностей, зокрема соціально-особистісних, фрахівців для роботи дистанційно. Явище дистанційної роботи, навчання онлайн сьогодні вже стало зрозумілим та невід'ємним для більшості роботодавців. Завдяки швидкому технологічному прогресу цифрова транссрормація стала сильною конкурентною перевагою для багатьох 
компаній, які прагнуть до успіху, зростання та масштабування. Але хоча цисррова транссрормація в глобальному масштабі вже почалася, пандемія змусила прискорити процес неймовірно швидкими темпами. COVID-19 повністю змінив звичний світ - від повсякденного життя людей до бізнес середовища, і змусив людство шукати колишній нормальний світ у віртуальній реальності. Це свідчить про необхідність створення нової універсальної моделі компетентностей - інструменту оцінки, який повинен змінюватися разом з компанією і середовищем, в кожній організації, яка перевела здебільшого працівників у дистанційний режим роботи.

На основі результатів аналізу принципів віддаленої роботи міжнародних та українських компаній, керуючись: системою Performance Management System, методичними матеріалами Національного Банку України [9] для оцінки корпоративних компетентностей та на основі узагальнення світового теоретичного та практичного досвіду розробки моделей компетентностей, а саме проекту Тюнінг [10], вважаємо за доцільне запропонувати наступні дев'ять ключових компетентностей що, визначають індивідуальні характеристики необхідні для успішної діяльності спеціаліста, що працює у дистанційному режимі та $\epsilon$ основними для забезпечення ефективної системи комунікацій, взаємодії різних ланок, а саме: ефрективне володіння часом (time-managment); комунікабельність; гнучкість; стресостійкість; старанність; цифррова грамотність; посидючість; відповідальність та прийняття рішення; здібність до навчання.

3 метою підтвердження важливості обраних дев'яти компетентностей для успішної діяльності спеціаліста було проведено експертне опитування (106 респондента) за допомогою електронного анкетування - сервіс Google Форми. [11] Цільовою аудиторією для електронного анкетування було обрано соціальні мережі LinkedIn (професійне середовище для пошуку і встановлення ділових контактів), Facebook, a caмe HR директори, менеджери, бізнес-партнери та роботодавці. Характеристика респондентів - їх кар'єрний рівень, досвід роботи, сорера діяльності наведені в табл. 1.

Результати опитування щодо важливості наявності компетентностей у працівників, що працюють у дистанційному режимі наведені в табл. 2. Розглянемо обрані компетентності більш детально та надамо їх визначення.

Компетентність ефрективне володіння часом (time-managment) - здатність визначати цілі і розставляти пріоритети, оцінювати дії, час і необхідні ресурси для їх досягнення.

\begin{tabular}{|c|c|}
\hline Категорія & $\begin{array}{c}\text { Кількість } \\
\text { респондентів, \% }\end{array}$ \\
\hline \multicolumn{2}{|c|}{ Вік } \\
\hline Молодше 20 років & 1 \\
\hline 20-24 років & 16,2 \\
\hline 25-34 років & 40,9 \\
\hline 35-44 років & 34,3 \\
\hline 45-50 років & 7,6 \\
\hline \multicolumn{2}{|c|}{ Кар'єрний рівень } \\
\hline Початковий & 4,7 \\
\hline Середній & 30,2 \\
\hline Старший & 47,2 \\
\hline Вищий виконавчий & 17,9 \\
\hline \multicolumn{2}{|c|}{ Сорера діяльності організації } \\
\hline Комерційна & 84 \\
\hline Неприбуткова & 2,8 \\
\hline Державна & 13,2 \\
\hline
\end{tabular}

Джерело: розроблено автором на підставі проведеного опитування

Компетентність комунікабельність це - здатність до спілкування, до пошуку сумісності, налагодження зв'язків з іншими людьми, вміння людини максимально якісно і адекватно застосовувати свої здібності вибудовування продуктивної взаємодії, уміння легко підбирати слова, бути впевненим у собі, по-своєму харизматичним, легко знаходити теми для розмов, незалежно від того, з ким спілкується, опускати особисті упередження щодо інших людей, їх способів організовувати власне життя, а також поглядів, цінностей і загального світогляду, чітко фрормувати мету комунікацій і надалі досягати її.

Компетентність гнучкість - це здатність реагувати на зміни в ситуації, зовнішньому середовищі та вибирати ефективний i адекватний спосіб дії відповідно до сфрормованих умов, вибирати відповідні комунікативні способи для досягнення результату в різних ситуаціях. Уміння змінювати способи діяльності та комунікації в залежності від обставин, приймати критику і зворотний зв'язок і коригувати свої дії щодо отриманої інформації.

Компетентність стресостійкість - здатність ефрективно працювати протягом довгого часу, вирішуючи одноманітні або трудомісткі завдання, справлятися 3 почуттям розчарування, невдачами і продовження рухатися вперед. Уміння спокійно ставиться до тиску ззовні та дуже швидко справлятися 3 напругою. 
Таблиця 2

Важливість наявності компетентностей у працівників, що працюють у дистанційному режимі

\begin{tabular}{|l|c|c|c|c|c|}
\hline \multirow{2}{*}{ Компетентності } & \multicolumn{5}{|c|}{ Рівень володіння, \% } \\
\cline { 2 - 6 } & $\begin{array}{c}\text { Недостатній } \\
\text { рівень }\end{array}$ & $\begin{array}{c}\text { Рівень } \\
\text { розуміння }\end{array}$ & $\begin{array}{c}\text { Базовий } \\
\text { рівень }\end{array}$ & $\begin{array}{c}\text { Рівень } \\
\text { досвіду }\end{array}$ & $\begin{array}{c}\text { Рівень } \\
\text { майстерності }\end{array}$ \\
\hline $\begin{array}{l}\text { едрективне володіння часом } \\
\text { (time-managment) }\end{array}$ & 0,9 & 1,9 & 10,4 & 61,3 & 25,5 \\
\hline комунікабельність & 1,9 & 2,8 & 39,6 & 34,9 & 20,8 \\
\hline гнучкість & 1,9 & 1,9 & 22,6 & 47,2 & 26,4 \\
\hline стресостійкість & 0,9 & 8,5 & 23,6 & 47,2 & 19,8 \\
\hline старанність & 0 & 1,9 & 29,2 & 43,4 & 25,5 \\
\hline цифррова грамотність & 2,8 & 2,8 & 14,2 & 35,8 & 46,2 \\
\hline посидючість & 1,9 & 6,6 & 25,5 & 37,7 & 28,3 \\
\hline $\begin{array}{l}\text { відповідальність } \\
\text { та прийняття рішення }\end{array}$ & 0 & 4,7 & 23,6 & 50,9 & 20,8 \\
\hline здібність до навчання & 0 & 8,5 & 26,4 & 45,3 & 19,8 \\
\hline
\end{tabular}

Джерело: розроблено автором на підставі проведеного опитування

Компетентність старанність - здатність і готовність чесно виконувати свої обов'язки. Вміння приймати і реалізовувати поставлені завдання, повністю завершити розпочате, планувати і працювати організовано, сконцентруватися на задоволенні потреб клієнта.

Компетентність здібність до навчання здатність легко вбирати нову інфрормацію і есрективно застосовувати її на практиці, адаптуватися до змін, самостійно оптимізувати методи роботи, інтегрувати новий досвід в практику.

Компетентність цисррова грамота - володіння пакетом MS Office на високому рівні, робота 3 електронною поштою, соціальними мережами. Впевнена робота з різними браузерами (Opera, Firefox, Chrome, Amigo, Internet Explorer). Навички роботи з операційною системою Windows.

Компетентність відповідальність та прийняття рішення - здатність виконувати доручену роботу, вирішувати труднощі самостійно рамках наявних повноважень, брати відповідальність за свої дії, приймати рішення, не звертаючись за вказівками до інших, діяти за власною ініціативою в рамках повноважень.

Компетентність посидючість - здатність тривалий час виконувати рутинні монотонні дії, протягом тривалого часу бути сконцентрованим на виконанні одного завдання, тривалий час проводити за екраном ПК.

Наведені дев'ять загальних компетентностей $є$ ключовими макрокомпетентностями, які знаходять прояв через відповідні поведінкові індикатори (табл.3), які виступають основою для побудови універсальної моделі компе- тентностей для працівників, які перейшли на дистанційний режим роботи.

На підставі проведеного дослідження та враховуючи класифрікацію компетентностей, яка запропонована Центром тестування та розвитку "Гуманітарні технології" [12] і запропонованих поведінкових індикаторів, пропонуємо універсальну модель компетентностей для працівників, що працюють у дистанційному режимі (рис. 1).

Для проведення оцінювання працівника на володіння компетентностями встановимо вагомість коефріцієнтів компетентностей в універсальній моделі компетентностей для працівників, що працюють в дистанційному режимі, використавши експертний метод бального оцінювання за інтервальною шкалою Лайкерта, в якій бал компетенції залежить від ступеня важливості її наявності (табл. 4). Шкала Лайкерта або шкала сумарних оцінок психометричні шкала, яка часто використовується в анкетах і анкетних дослідженнях [13].

Вагові коефріцієнти компетентностей визначаються на основі балів за шкалою Лайкерта, які виставляються експертами та відображають їх просресійну думку щодо важливості певної компетентності для працівника, що працює в дистанційному режимі. У експертному опитуванні були задіяні 20 експертів з числа досвідчених HR-фрахівців та HR-директорів різних компаній України [14]. Вказана кількість експертів є досвідченою професійною, цільової експертною групи, яка розуміє визначальні фрактори результативної діяльності працівника в дистанційному режимі та цілком оптимальна для визначення вагових коефріцієнтів компетентностей. 
Таблиця 3

\section{Поведінкові індикатори}

\begin{tabular}{|c|c|}
\hline Компетентність & Поведінкові індикатори \\
\hline $\begin{array}{l}\text { есрективне } \\
\text { володіння часом } \\
\text { (time-managment) }\end{array}$ & $\begin{array}{l}\text { - при отриманні завдання від керівника, уточнює критерії кінцевого результату, } \\
\text { терміни виконання доручень, періодичність контролю та відповідні ресурси; } \\
\text { - вірно розставляє пріоритети в стандартних робочих ситуаціях, оперативно } \\
\text { коригує свої плани, враховуючи нові завдання; } \\
\text { - враховує терміни виконання завдань, виправляє помилки в разі відхилення від } \\
\text { термінів виконання; } \\
\text { - виконує роботу якісно, завжди закінчує почате завдання; } \\
\text { - стикаючись з труднощами, адекватно оцінює свої можливості і ресурси, } \\
\text { береться за вирішення посильних проблем. У разі, якщо розуміє, що не може } \\
\text { самотужки впоратися з проблемою, оперативно інорормує керівника і зацікавлені } \\
\text { сторони про виникнення труднощів }\end{array}$ \\
\hline комунікабельність & $\begin{array}{l}\text { - вміє спілкуватися на робочі теми конструктивно, у справі і результативно; } \\
\text { - здатний до позитивного спілкування, вміє підтримувати контакт з керівництвом, } \\
\text { підлеглими і колегами; } \\
\text { - володіє вербальної культурою, володіє словом, не проявляє недорікуватість; } \\
\text { - здатний підтримувати довгострокові відносини з партнерами по бізнесу; } \\
\text { - вміє регулювати ділові конолікти }\end{array}$ \\
\hline гнучкість & $\begin{array}{l}\text { - проявляє бажання працювати над завданнями за рамками прийнятого порядку, } \\
\text { тобто відходить від своїх початкових планів, але здатний повернутися до них, щоб } \\
\text { всі дії були ефрективно завершені; } \\
\text { - застосовує правила або процедури гнучко, в залежності від конкретної ситуації, } \\
\text { для більш ефективног виконання завдань або заходів; } \\
\text { - здатен змінювати свій підхід або стиль під впливом мінливих обставин; } \\
\text { - визначає прагматичний підхдд для того, щоб виконати роботу швидко і ефективно; } \\
\text { - здатен змінювати загальний план, мету або проект, щоб відповідати ситуації }\end{array}$ \\
\hline стресостійкість & $\begin{array}{l}\text { - здатний надати відповідні відповіді і підтримувати стандарти якості, незважаючи } \\
\text { на тиск; } \\
\text { - вміє тримає емоції під контролем при зіткненні з конфронтацією; } \\
\text { - у стресовій ситуації здатнии ссрокусуватися на важливих моментах, а не } \\
\text { втягуватися в суперечки; } \\
\text { - не втрачає з уваги головні цілі і загальні вимоги, незважаючи на важливі } \\
\text { зовнішні фактори тиску; } \\
\text { - підтримує зрілу та стриману точку зору і приймає об'єктивні рішення, } \\
\text { незважаючи на тиск }\end{array}$ \\
\hline старанність & $\begin{array}{l}\text { - готовий приймати та реалізовувати поставлені задачі; } \\
\text { - здатний доводити справи до кінця - завершувати завдання та роботу; } \\
\text { - вміє працювати організовано, дотримуватися дедлайнів }\end{array}$ \\
\hline цифррова гр & $\begin{array}{l}\text { - впевнено працює з пакетом Microsoft Office; } \\
\text { - володіє навичками роботи з електронною поштою; } \\
\text { - впевнене володіння роботи з різними браузерами; } \\
\text { - здатний користуватися програмами для зв'язку та відео-конференцій: Zoom, } \\
\text { Skype, Google Meet }\end{array}$ \\
\hline посидючість & $\begin{array}{l}\text { - беручи завдання в роботу, оцінює ресурси і робить висновки, за рахунок чого } \\
\text { вдасться цю мету досягти; } \\
\text { - прораховує ситуацію на крок вперед; } \\
\text { - демонструє завзятість, наполегливість в досягненні поставленої мети: робить } \\
\text { кілька спроб, але вирішує поставлене перед ним завдання; } \\
\text { - підтримує концентровану увагу; } \\
\text { - проводить ретельний аналіз інформації; } \\
\text { - проявляє високу працездатність }\end{array}$ \\
\hline $\begin{array}{l}\text { відповідальність } \\
\text { та прийняття } \\
\text { рішення }\end{array}$ & $\begin{array}{l}\text { - здатний брати відповідальність за свої дії і дії своїх підлеглих (керівні посади), } \\
\text { готовність брати на себе додаткові фрункції, навіть якщо вони не входять в сферу } \\
\text { особистої відповідальності; } \\
\text { - здатний прийняти і усвідомити власну провину при неправильно прийнятому рішенні; } \\
\text { - аналізує проблемну ситуацію, знаходить оптимальні шляхи вирішення проблеми; } \\
\text { - приймає рішення, ґрунтуючись на точному аналізі з урахуванням комерційної } \\
\text { вигоди для компанії; } \\
\text { - вміє обґрунтувати прийняте рішення і визначити порядок дій. }\end{array}$ \\
\hline $\begin{array}{l}\text { здібність до } \\
\text { навчання }\end{array}$ & $\begin{array}{l}\text { - здатний до навчання, відкритий до сприйняття нової інформації; } \\
\text { - вміє застосовувати наявні знання та досвід на практиці та у нетипових ситуаціях; } \\
\text { - визнає свої помилки і намагається виправити або запобігати їм, готовий вчитися } \\
\text { на власних помилках; } \\
\text { - виробляє нові ідеї та пропозиції після навчання і опрацьовує питання, пов'язані } 3 \\
\text { його позицією; } \\
\text { - здатний опановувати нові знання та навички та підлаштовуватися під зміни в } \\
\text { середовищі }\end{array}$ \\
\hline
\end{tabular}




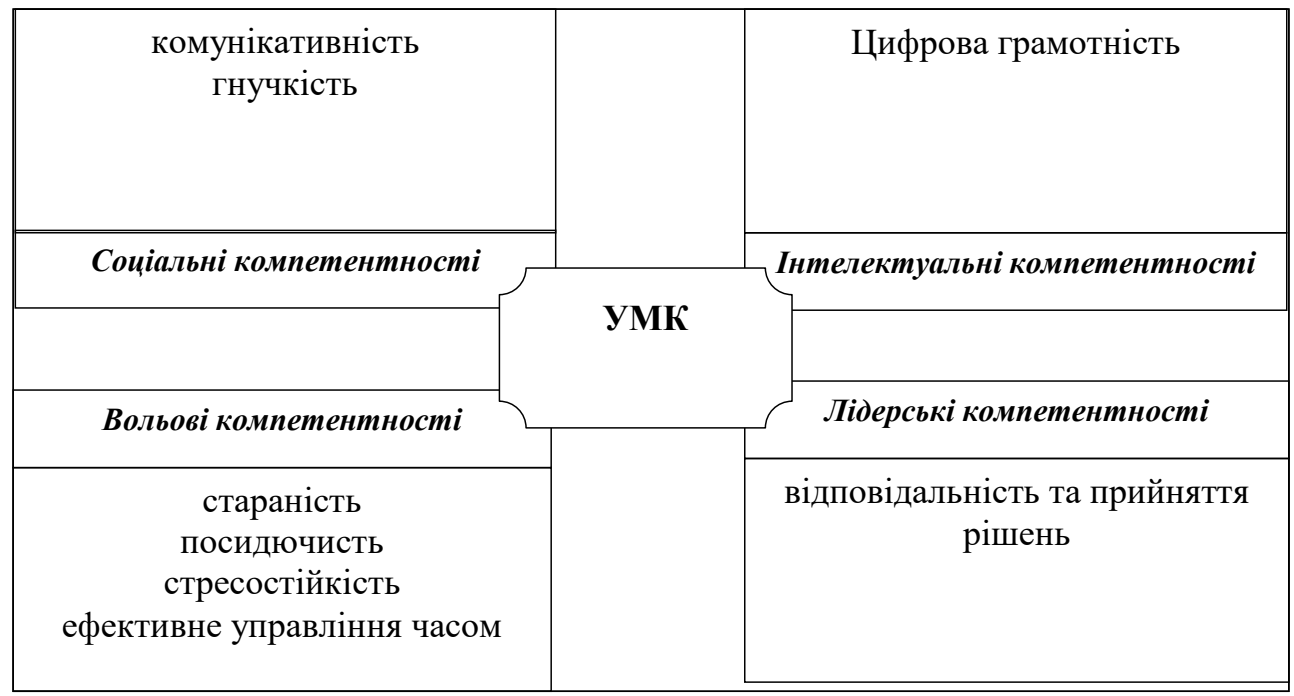

Рис. 1. Універсальна модель компетентностей працівників, що працюють у дистанційному режимі

Джерело: розроблено автором

Вагомість компетентностей визначається фрормулою 1, відношенням суми балів за i-тою компетентністю до загальної суми балів за усіма компетентностями, але сума вагових коефріцієнтів всіх компетентностей має дорівнювати одиниці:

$$
\alpha_{i}=\frac{\sum_{i=1}^{n} y_{i}\left(E_{t}\right)}{\sum_{i=1}^{n} \sum_{i=1}^{n} y_{i}}
$$

де $\alpha_{i}$ - ваговий коефріцієнт $i$-тої компетентHOCTi;

i - номер компетентності;

$y_{i}\left(E_{t}\right)$ - бал присвоєний $i$-тій компетентності експертом;

$\sum y_{i}\left(E_{t}\right)$ - сума балів всіх експертів за $i$-тою компетентністю;

$\sum \sum y_{i}\left(E_{t}\right)$ - сума балів всіх експертів за всіма компетентностями.

Шкала сумарних оцінок Лайкерта

Таблиця 4

\begin{tabular}{|c|c|}
\hline Рейтинг (бали) & Шкала оцінок \\
\hline 0 & $\begin{array}{l}\text { Абсолютно не важливо. } \\
\text { Відповідність поведінковим індикаторам компетентності не потрібна } \\
\text { для виконання службових обов'язків та не може впливати, будь-яким } \\
\text { чином, на поточну ефрективність працівника. } \\
\end{array}$ \\
\hline 1 & $\begin{array}{l}\text { Не дуже важливо. } \\
\text { Відсутність відповідність поведінковим індикаторам компетентності здійснює } \\
\text { відносно незначний вплив на поточну ефрективність виконання робіт праців- } \\
\text { ником. Без цієї компетентності працівник може ефективно виконувати роботу. }\end{array}$ \\
\hline 2 & $\begin{array}{l}\text { Може бути важливо. } \\
\text { Відсутність відповідність поведінковим індикаторам компетентності може } \\
\text { здійснювати відносно значний вплив на поточну ефективність виконання } \\
\text { робіт працівником. Без цієї компетентності працівник не може ефективно } \\
\text { виконувати роботу. }\end{array}$ \\
\hline 3 & $\begin{array}{l}\text { Дуже важливо. } \\
\text { Відповідність поведінковим індикаторам компетентності має важливий } \\
\text { вплив на ефективність виконання робіт працівником. Без цієї компетентності } \\
\text { працівнику складно ефективно виконувати професійні обов'язки. }\end{array}$ \\
\hline 4 & $\begin{array}{l}\text { Абсолютно важливо. } \\
\text { Відповідність поведінковим індикаторам компетентності має критично } \\
\text { важливий вплив на ефективність виконання робіт працівником. Без цієї } \\
\text { компетентності працівник не може виконувати свої профресійні обов'язки. }\end{array}$ \\
\hline
\end{tabular}


Розрахунок вагових коефріцієнтів компетентностей працівника, що працює в дистанційному режимі

\begin{tabular}{|c|c|c|}
\hline Компетентності & $\begin{array}{c}\text { Сума балів експертів } \\
\text { за компетентністю, } \\
\sum y_{i}\left(E_{t}\right)\end{array}$ & $\begin{array}{l}\text { Ваговий коефріцієнт } \\
\text { компетентності, } \alpha_{i}\end{array}$ \\
\hline $\begin{array}{l}\text { ефрективне володіння часом } \\
\text { (time-managment) }\end{array}$ & 66 & 0,134 \\
\hline комунікабельність & 53 & 0,107 \\
\hline гнучкість & 52 & 0,105 \\
\hline стресостійкість & 45 & 0,091 \\
\hline старанність & 56 & 0,113 \\
\hline цифрова грамота & 60 & 0,121 \\
\hline посидючість & 51 & 0,103 \\
\hline відповідальність та прийняття рішення & 57 & 0,115 \\
\hline здібність до навчання & 54 & 0,109 \\
\hline$\sum \sum y_{i}\left(E_{t}\right)$ & 494 & 1,0 \\
\hline
\end{tabular}

Джерело: розраховано автором на основі опитування

За результатами експертного опитування та обробки отриманих даних за методикою розрахунку вагових коефріцієнтів за наведеною фрормулою, було отримано вагові коефріцієнти для інтегрального показника компетентності працівника для кожної з дев'яти компетентностей (табл. 5). Інтегральний показник компетентності працівника, це - показник у якому відтворюються значення всіх дев'яти компетентностей, скоригованих у відповідності до їх вагомості.

Для визначення наявності компетентностей працівника пропонується розробити оцінювальні анкети на підставі запропонованих поведінкових індикаторів до кожної компетентності, які наведено в табл. 3. Кожен працівник оцінюється за дев'ятьма компетентностями та поведінковими індикаторами, які притаманні кожній компетентності (табл. 3). Керівництву або експертній комісії, яка створена в компанії для оцінювання працівників, пропонується здійснювати оцінювання за наступною бальною шкалою:

- 0 - повна відсутність певного індикатору поведінки за певною компетентністю;

- 0,5 - його часткова присутність;

- 1 - чітка наявність даного індикатору поведінки у працівника.

Експертна комісія може складатися з п'яти експертів - HR-менеджера, безпосереднього керівника структурного підрозділу, лінійного менеджеру та керівників суміжних підрозділів з якими взаємодіє особа що оцінюється. Після заповнення оцінювальних анкет відбувається розрахунок середніх значень індикаторів поведінки за балами експертів та визначення середніх значень компетентностей працівника відповідно за фоормулами (2) та (3):

$$
\overline{X_{i, j}}=\frac{\sum_{t=1}^{t} X_{i j}\left(E_{t}\right)}{t}
$$

де $\overline{X_{i, j}}-$ середнє значення $j$-го індикатора поведінки $i$-тої компетентності за балами експертів;

$t$ - кількість експертів, що прийняли участь в оцінюванні;

i - порядковий номер компетентності;

$j$ - порядковий номер індикатора поведінки в компетентності;

$X_{i, j}$ - значення j-го індикатора поведінки i-тої компетентності за балами експертів;

$X_{i, j}\left(E_{t}\right)$ - середнє значення $j$-го індикатора поведінки $i$-тої компетентності $t$-го експерту;

$$
X_{i}=\frac{\sum_{t=1}^{n} \overline{X_{i, j}}}{n}
$$

де $X_{i}$ - значення $i$-тої компетентності;

$\overline{X_{i, j}}$ - середнє значення j-го індикатора поведінки і-тої компетентності за балами експертів;

$n$ - кількість індикаторів поведінки в кожній компетентності.

Отримані результати середніх значень компетентностей пропонуємо інтерпретувати за шкалою (фрункція бажаності) Харінгтона [15], яка наведена в табл. 6.

Для прийняття управлінського рішення щодо працівника, при оцінюванні розраховується інтегральний показник компетентності працівника на основі запропонованих вагових 
Шкала Харінгтона

Таблиця 6

\begin{tabular}{|l|c|c|}
\hline \multicolumn{1}{|c|}{$\begin{array}{c}\text { Рівень (Функція } \\
\text { Харингтона) }\end{array}$} & $\begin{array}{c}\text { Межі значень бальної } \\
\text { шкали для оцінки } \\
\text { індикаторів Мк }\end{array}$ & $\begin{array}{c}\text { Діапазони якості оцінки } \\
\text { компетентності }\end{array}$ \\
\hline Нижчий рівень & $(0-0,2]$ & дуже погано \\
\hline Рівень нижче середнього & $(0,2-0,37]$ & погано \\
\hline Середній рівень & $(0,37-0,63]$ & задовільно \\
\hline Рівень вище середнього & $(0,63-0,8]$ & добре \\
\hline Високий рівень & $(0,8-1,0]$ & дуже добре \\
\hline
\end{tabular}

Джерело: розроблено на основі [15]

коефріцієнтів та значень компетентностей, які були визначені, за наступною фрормулою (4):

$$
I=\sum x_{i} \times \alpha_{i}
$$

де $I$ - інтегральний показник компетентності працівника;

$x_{i}$ - значення балів $i$-тої компетентності працівника;

$\alpha_{i}$ - коефріцієнт вагомості $i$-тої компетентності.

Інтерпретацію інтегрального показника компетентності працівника пропонується здійснити за допомогою шкали Харінгтона [15], що надає можливості керівництву компанії для прийняття управлінських рішень. Якщо працівник має в результаті оцінювання діапазони якості оцінки компетентності “дуже погано” або “погано”, в такому разі керівник має організувати його роботу в офрісі та підібрати програму навчання або тренінги для розвитку непроявлених компетентностей. Якщо працівник має в результаті оцінювання діапазони якості оцінки компетентності "задовільно", керівник може організувати змішану форму роботи, частково в офрісі, частково в дистанційному режимі, 3 направленням на навчання або тренінги для розвитку непроявлених компетентностей. Якщо працівник має в результаті оціню- вання діапазони якості оцінки компетентності "добре" та "дуже добре", в такому випадку керівник може встановити повністю дистанційний режим роботи, з наданням самостійності у виконанні професійних завдань.

Висновки. У наш швидкоплинний час зміни потребують від бізнесу відповідних дій, особливо у процесах управління персоналом. Універсальна модель компетентностей для працівників, які перейшли на дистанційний режим роботи $€$ лише фррагментом універсальної моделі компетентностей фрахівця 3 орінансів, рекрутингу, маркетингу, управління персоналом - будь-якої галузі. Результати та ефективність роботи працівників в дистанційному режимі цілком залежить від відповідних дій керівника, які мають бути узгоджені з вимогами онлайн середовища, а також від рівня розвитку необхідних компетентностей, які $\epsilon$ базовими. Для розробки методичного забезпечення розвитку просресійної компетентності персоналу необхідні подальші дослідження 3 урахуванням конкретного роду діяльності працівника - посади, особливостей сфери діяльності організації, її господарського середовища та конкурентних стратегій розвитку.

\section{СПИСОК ВИКОРИСТАНИХ ДЖЕРЕЛ:}

1. Колот А.М. Соціально-трудова реальність - XXI: фрілософрія становлення, можливостей та викликів. Економіка України. 2021. № 2. С. 03-31. URL: https://doi.org/10.15407/economyukr.2021.02.003 (дата звернення: 20.04.2021).

2. Лопушняк Г.С., Миляник Р.В. Вплив цифррових технологій на формування компетенцій управлінського персоналу. Інвестиції: практика та досвід. 2019. № 24. С. 10-16. URL: http://www.investplan.com.ua/ pdf/24_2019/4.pdf (дата звернення: 20.04.2021).

3. Petrova I., Balyka O., Kachan H. Digital economy, and digital employment appearence. Social and labour relations: theory and practice. 2020. 10(2). Pp. 10-20. doi:10.21511/slrtp.10(2).2020.02 (дата звернення: 20.04.2021).

4. Цимбалюк С.А., Пинчук В.А. Оценка конкурентоспособности системы управления персоналом с использованием инструментария бенчмаркинга. Бизнес Инфрорм. 2019. № 5(496).

5. Кравчук О.І. Цифрова компетентність менеджера з персоналу. Соціально-трудові відносини: теорія $i$ практика. 2018. № 1. С. 172-191.

6. Волобоєва І.О. Механізм фрормування та впровадження моделі компетенцій. Соціально-трудові відносини: теорія і практика. 2018. № 1. С. 360-366. 
7. Про освіту : Закон України від 05.09.2017 № 2145-VIII. URL: https://zakon.rada.gov.ua/laws/show/2145-19 (дата звернення: 23.03.2021).

8. Сисоєва С.О. Різниця понять. чи постраждає зміст закону? Газета "Освіта". 17-24 червня 2015 р. № 26-27. URL: http://naps.gov.ua/ua/press/about_us/726/

9. Малыш Ю., Апарин В. Система управления исполнением в Национальном банке Украины. Менеджер по персоналу. 2018. № 3. С. 12-20. URL: https://old.bank.gov.ua/doccatalog/document?id=68228085 (дата звернення: 17.04.2021).

10. Tuning Academy. URL: http://tuningacademy.org/ (дата звернення: 22.03.2021).

11. Оцінка важливості ключових компетентностей для працівників, які перейшли на дистанційний режим роботи. URL: https://forms.gle/SC5M9kNA99yPTARu8 (дата звернення: 23.04.2021).

12.БикУлЛОВа О. 20 SOFT SKILLS ДЛЯ БУДУЩЕЙ КАРЬЕРЫ: КАК И КОГДА РАЗВИВАТЬ? URL: https://proforientator.ru/publications/articles/20-soft-skills-dlya-budushchey-karery-kak-i-kogda-razvivat.html (дата звернення: 17.04.2021).

13. Likert scale. URL: https://en.wikipedia.org/wiki/Likert_scale (дата звернення: 15.04.2021).

14.Важливість певної компетентності для для працівника, що працює в дистанційному режимі. URL: https://forms.gle/pGxZsjuNw9gJ98UPA (дата звернення: 17.04.2021).

15. Harrington, E.C. The desirable function. Industrial Quality Control. 1965. V. 21. № 10. P. 494-498.

\section{REFERENCES:}

1. Kolot A.M. (2021). Sotsialno-trudova realnist - XXI: filosofiia stanovlennia, mozhlyvostei ta vyklykiv [Sociolabor reality - XXI: philosophy of formation, opportunities and challenges]. Ekonomika Ukrainy, no. 2, pp. 03-31. https://doi.org/10.15407/economyukr (in Ukrainian)

2. Lopushniak H.S., Mylianyk R.V. (2019). Vplyv tsyfrovykh tekhnolohii na formuvannia kompetentsii upravlinskoho personalu [The influence of digital technologies on the formation of competencies of management staff ]. Investytsii: praktyka ta dosvid, no. 24, pp. 10-16. Available at: http://www.investplan.com.ua/pdf/24_2019/4.pdf (in Ukrainian)

3. Petrova I., Balyka O., Kachan H. (2020). Digital economy, and digital employment appearence. Social and labour relations: theory and practice, 10(2), pp. 10-20. https://doi:10.21511/slrtp.10(2).2020.02

4. Cimbalyuk S.A., Pinchuk V.A. (2019). Ocenka konkurentosposobnosti sistemy upravleniya personalom s ispol'zovaniem instrumentariya benchmarkinga [Assessment of the competitiveness of the personnel management system using benchmarking tools]. Biznes Inform, no. 5(496). (in Russian)

5. Kravchuk O.I. (2018). Tsyfrova kompetentnist menedzhera z personalu [Digital competence of a personnel manager]. Sotsialno-trudovi vidnosyny: teoriia i praktyka, no. 1, pp. 172-191. (in Ukrainian)

6. Voloboieva I.O. (2018). Mekhanizm formuvannia ta vprovadzhennia modeli kompetentsii [The mechanism of formation and implementation of the competency model]. Sotsialno-trudovi vidnosyny: teoriia i praktyka, no. 1, pp. 360-366. (in Ukrainian)

7. Law of Ukraine on the education № 2145-VIII (2017, September 05). Available at: https://zakon.rada.gov.ua/ laws/show/2145-19 (in Ukrainian)

8. Sysoieva S.O. Riznytsia poniat. chy postrazhdaie zmist zakonu? [The difference of concepts. Will the content of the law be affected?]. Hazeta "Osvita". 17-24 chervnia 2015 r. № 26-27. Available at: http://naps.gov.ua/ua/press/ about_us/726/(in Ukrainian)

9. Tuning Academy. Available at: http://tuningacademy.org/

10. Malysh Yu., Aparin V. (2018). Sistema upravleniya ispolneniem v Natsionalnom banke Ukrainy [Execution management system in the National Bank of Ukraine]. Menedzher po personalu, no. 3, pp. 12-20. Available at: https://old.bank.gov.ua/doccatalog/document?id=68228085 (in Russian)

11. Otsinka vazhlyvosti kliuchovykh kompetentnostei dlia pratsivnykiv, yaki pereishly na dystantsiinyi rezhym roboty [Assess the importance of key competencies for employees who have switched to remote work]. Available at: https://forms.gle/SC5M9kNA99yPTARu8 (in Ukrainian)

12. Bikullova O. 20 soft skills dlya budushchyey karyery: kak i kogda razvivat? [20 soft skills for future careers: how and when to develop?] Available at: https://proforientator.ru/publications/articles/20-soft-skills-dlya-budushchey-karery-kak-i-kogda-razvivat.html (in Russian)

13. Likert scale. Available at: https://en.wikipedia.org/wiki/Likert_scale

14. Vazhlyvist pevnoi kompetentnosti dlia dlia pratsivnyka, shcho pratsiuie $v$ dystantsiinomu rezhymi [The importance of a certain competence for a worker working remotely]. Available at: https://forms.glepGxZsjuNw9gJ98UPA (in Ukrainian)

15. Harrington E.C. (1965) The desirable function. Industrial Quality Control, vol. 21, no. 10, pp. 494-498. 